\title{
The Effects of Different NPK Fertilization Rates and Water Regimes on Ratooned Black Glutinous Rice
}

\author{
Benyamin Lakitan $^{1,2 *}$, Karla K. Jaya ${ }^{1}$, Rofiqoh P. Ria ${ }^{1}$, \\ and Badai Morianto ${ }^{1}$
}

${ }^{I}$ College of Agriculture, Universitas Sriwijaya, Inderalaya 30662, Indonesia

${ }^{2}$ Research Center for Sub-optimal Lands (PUR-PLSO), Universitas Sriwijaya, Palembang 30139, Indonesia

*Corresponding author. E-mail: blakitan60@unsri.ac.id https://doi.org/10.12982/CMUJNS.2020.0023

Received: April 11, 2019

Revised: July 13, 2019

Accepted: August 19, 2019

\begin{abstract}
Ratooned rice crop is a strategy for increasing rice production at short second rice growing season at riparian wetland under unpredictable climatic condition. The objective of this research was to evaluate vegetative growth and potential grain yield in ratooned black glutinous rice exposed to continuous flooding at 3-cm depth, alternate wetting-drying condition, and shallow water table during second rice growing season at riparian wetland. These three water regimes simulate the possibilities of unfavorable conditions, i.e. prolonged rainy season, inconsistent rain distribution, and early transition of rainy-to-dry season. In addition to water regime treatments, the ratooned rice was enriched with three NPK (15-15-15) rates equivalent to 80, 160, 240, and $320 \mathrm{~kg} / \mathrm{ha}$. Results indicated that total and productive tillers, leaf and stem dry weight, number of leaves, percentage of filled grain, and grain yield were significantly affected by water regimes; while NPK application rates significantly affected total and productive tillers, number of leaves, and grain yield. Continuous flooding effectively controlled weed outburst during cultivation of ratooned rice. Therefore, it contributed to better rice vegetative growth and grain yield than those exposed to alternate wetting-drying or shallow water table condition. The highest grain yield was found at $320 \mathrm{~kg} / \mathrm{ha}$ NPK application rate. Number of productive tillers was highly correlated with grain yield $(r=0.8499)$ while total number of tillers was moderately reliable $(r=0.6334)$ and can be used as an early predictor for grain yield in ratooned rice.
\end{abstract}


Keywords: Continuous flooding, Alternate wetting-drying, Shallow water table, Glutinous rice, Riparian wetland.

\section{INTRODUCTION}

Rice growing period at riparian wetlands is limited by two extremes like the prolonged flooding and severe drought during wet and dry season, respectively (Lakitan et al., 2018a). Local rice farmers prefer early transplanting after the floodwater subsides at $<15 \mathrm{~cm}$ (Lakitan et al., 2019a). Since the depths of floodwater vary each season, the start and end of rice cultivation are also affected. However, there are few parts of riparian wetlands which rice cultivation can be done twice a year. These are the shallowly and short-period flooded wetlands. Most of the areas are cultivated with rice once a year, then vegetables with short life cycles such snap bean, water spinach (Ipomoea aquatica), yellow velvet leaf (Limnocharis flava), or other leafy vegetables often follows (Meihana et al., 2017; Widuri et al., 2017; 2018; Lakitan et al., 2018b; 2019b; Susilawati and Lakitan, 2019). However, only few farmers have thrived to rice-vegetables cropping pattern due to vegetables grown after rice crop could be exposed to drought stress if dry season comes earlier than expected or flooded and fully submerged if wet season comes earlier as well. If likely drought occurs, watering the vegetables will be costlier than cultivating rice continually. On the other hand, flooding can cause severe or total crop loss, especially to vegetables.

Ratooned rice can also be practiced for intensifying rice production in areas where growing season are considerably longer than required for single rice cultivation but not long enough for double-cropping rice (Chen et al., 2018). Ratooned rice was an effective and low-cost practice that could add grain yield by about half of previously harvested grains of the main rice crop (Sen and Bond, 2017; Ziska et al., 2018; Yuan et al., 2019). Higher regeneration rates of the stump contributed to the higher yield in ratooned rice. Further research indicated that higher stump regeneration rate was found at $40-\mathrm{cm}$ stem cutting height at harvesting of the main rice crop (Mareza et al., 2016; Hafeez et al., 2017).

Different water regimes are expected to impose different effect on grain yield in ratooned rice. Continuous flooding or waterlogging condition may benefit the ratooned rice since floodwater and anaerobic substrate will suppress weed growth and development. However, alternate wetting and drying condition has also been reported of having advantages, including increasing nitrogen availability, nitrogen uptake, and efficiency of nitrogen recovery (de Borja-Reis et al., 2018; Sun et al., 2019).

Previous rates and split applications of inorganic fertilizers to main rice crop did not affect grain yield of the following ratooned crop (Chen et al., 2010; Adigbo et al., 2017), suggesting that the applied fertilizers had been fully depleted during four months of main rice cultivation. Re-application of fertilizers was 
recommended for the ratooned crop. Nitrogen application at beginning of ratooning period significantly increased growth and grain yield in ratooned rice (Huossainzade et al., 2011; Petroudi et al., 2011)

Objective of this research was to evaluate influences of different NPK application rates at initiation of ratooning period and exposure to different water regimes during cultivation on growth and grain yield in ratooned black glutinous rice.

\section{MATERIALS AND METHODS}

\section{Plant materials}

Black glutinous rice (Oryza sativa L. subspecies indica) used was Toraja variety. Color of grain surface of this variety is actually dark purple. This black glutinous rice has high total phenolic compound, anthocyanin content, antioxidant activity, and lower glycemic index (Thiranusornkij et al., 2019).

\section{Seedling preparation and cultivation procedure for main rice crop}

Seedling preparation for main rice crop was commenced at time floodwater had subsided to about $20 \mathrm{~cm}$, using floating seedbed. Soil-manure mix was used as nursery substrate. Seeds were soaked in tap water for 24 hours before sowing. The seeds were dispersed on surface of wet nursery substrate on floating seedbed. Seedlings were nurtured on the raft until they were ready to be transplanted at 3 weeks after sowing.

Five seedlings were transplanted into each pot containing similar soilmanure mix. After one week of acclimatizing, three most vigorous seedlings were kept (the other two were excised) for study on growth and yield of the main crops. NPK fertilizer used contains $15 \% \mathrm{~N}, 15 \% \quad \mathrm{P}_{2} \mathrm{O}_{5}$, and $15 \% \mathrm{~K}(15-15-15)$. Application of the NPK fertilizer to main crops was at total rate equivalent to 200 $\mathrm{kg} / \mathrm{ha}$, split equally between the first and fifth week after transplanting. The main crops were protected from insect pests, plant diseases, and weeds until harvest.

\section{Treatments to ratooned black glutinous rice}

Ratooning experiment was started after all stumps of main rice were cut at height of $15 \mathrm{~cm}$ above substrate surface. Ratooned rice was treated with four NPK application rates and exposed to three different water regimes. The NPK application and water regime treatments were immediately commenced on the next day after the stumps were cut. Rates of NPK application were $0.5 \mathrm{~g} / \mathrm{hill}(\mathrm{P} 1)$, $1.0 \mathrm{~g} / \mathrm{hill}(\mathrm{P} 2), 1.5 \mathrm{~g} / \mathrm{hill}(\mathrm{P} 3)$, and $2.0 \mathrm{~g} / \mathrm{hill}$ (P4). These rates were equivalent to $80 \mathrm{~kg} / \mathrm{ha}(\mathrm{P} 1), 160 \mathrm{~kg} / \mathrm{ha}(\mathrm{P} 2), 240 \mathrm{~kg} / \mathrm{ha}$ and $320 \mathrm{~kg} / \mathrm{ha}$ at planting spacing of 25 $\mathrm{cm} \times 25 \mathrm{~cm}$.

Water regimes exposed to the ratooned rice were continuous flooding, water level was maintained at $3 \mathrm{~cm}$ above substrate surface (W1); alternate wetting and drying, water level was allowed to fluctuate between $3 \mathrm{~cm}$ above and $3 \mathrm{~cm}$ below substrate surface (W2); and shallow water table, water level was 
maintained at $3 \mathrm{~cm}$ below substrate surface (W3) by drilling 4 drainage holes, positioned at perfect cross-sectional sides of each pre-assigned pot at $3 \mathrm{~cm}$ below substrate surface. The four holes automatically drained out excess water in upper $3-\mathrm{cm}$ substrate layer and maintained this upper layer at well aerated condition. Alternate wetting and drying treatment was done by plugging and unplugging the side drainage holes alternately every 3 -day cycle.

\section{Measured traits and data collection}

Directly measured or calculated traits included total tillers per hill, productive tillers per hill, average length of peduncle, number of grains per peduncle, grain density, total grain weight per peduncle, percentage of filled grain per peduncle, average weight of grain, number of leaves at harvest, leaf dry weight at harvest, stem dry weight at harvest, and grain yield.

Number of productive tillers was counted based on tillers which produced peduncle. Grain density was calculated based on ratio between number of grain and length of peduncle. Grain yield was calculated based on multiplication of total hills per hectare at $25 \mathrm{~cm} \times 25 \mathrm{~cm}$ spacing, number of productive tillers, number of filled grains per peduncle, and average weight of grain.

Weeds were not controlled during ratooned rice cultivation in order to evaluate their effect on growth and yield in ratooned rice, as an indirect effect of water regime treatment. Weeds were collected and identified at time of harvest. Total dry weight of weeds was measured.

\section{Statistical analysis}

Collected data in this experiment were subjected to the Analysis of Variance (ANOVA) using statistical analysis software (SAS 9.0 for Windows). Since substrate used in this pot experiment has been well mixed; therefore, differences in measured parameters were mostly due to effectiveness of NPK application and effect of water regimes. Experimental design used was factorial design with two factors, i.e. 3 different water regimes and 4 NPK application rates. Based on results of ANOVA, treatments exhibited significant effects on any measured parameters were further tested using the Least Significant Difference (LSD) test at $P \leq 0.05$. Correlations of selected vegetative and reproductive traits with grain yield were tested for further use as in-season predictor of grain yield (Chipanshi et al., 2015).

\section{RESULTS}

Vegetative traits were more sensitive than reproductive traits on exposure to water regimes and NPK application rates in black glutinous rice. Total and productive tillers, leaf and stem dry weight, and number of leaves per plant were significantly suppressed by water regime; while among measured reproductive traits, only percentage of filled grain and grain yield were affected. Higher NPK application rates significantly increased total and productive tillers, number of 
leaves, and grain yield (Table 1). Interactions between the two treatments were also observed on similar traits with addition of total grain weight per peduncle.

Table 1. Effects of water regime and NPK rate on yield components and some vegetative traits in ratooned black glutinous rice.

\begin{tabular}{llllllll}
\hline \multirow{2}{*}{ No. } & Trait & \multicolumn{2}{l}{$\begin{array}{l}\text { Water } \\
\text { regime }\end{array}$} & \multicolumn{2}{c}{ NPK rate } & \multicolumn{2}{l}{ Interaction } \\
\hline 1 & Total tiller & 8.24 & $* *$ & 4.15 & $* *$ & 4.44 & $* *$ \\
2 & Productive tiller & 6.20 & $* *$ & 3.91 & $*$ & 2.50 & $*$ \\
3 & Peduncle length & 0.03 & $\mathrm{~ns}$ & 0.91 & $\mathrm{~ns}$ & 1.19 & $\mathrm{~ns}$ \\
4 & Grain/peduncle & 2.18 & $\mathrm{~ns}$ & 0.38 & $\mathrm{~ns}$ & 2.00 & $\mathrm{~ns}$ \\
5 & Grain density & 1.36 & $\mathrm{~ns}$ & 0.62 & $\mathrm{~ns}$ & 1.65 & $\mathrm{~ns}$ \\
6 & Total grain weight/peduncle & 0.53 & $\mathrm{~ns}$ & 1.76 & $\mathrm{~ns}$ & 3.12 & $*$ \\
7 & Average weight of grain & 1.07 & $\mathrm{~ns}$ & 2.64 & $\mathrm{~ns}$ & 1.99 & $\mathrm{~ns}$ \\
8 & Number of filled grain/peduncle & 0.65 & $\mathrm{~ns}$ & 0.43 & $\mathrm{~ns}$ & 1.85 & $\mathrm{~ns}$ \\
9 & Percentage of filled grain & 5.11 & $* *$ & 2.64 & $\mathrm{~ns}$ & 2.19 & $\mathrm{~ns}$ \\
10 & Number of leaves & 5.08 & $* *$ & 3.41 & $*$ & 7.25 & $* *$ \\
11 & Leaf dry weight & 5.66 & $* *$ & 1.68 & $\mathrm{~ns}$ & 3.21 & $* *$ \\
12 & Stem dry weight & 9.07 & $* *$ & 2.43 & $\mathrm{~ns}$ & 3.32 & $* *$ \\
13 & Grain yield & 5.45 & $* *$ & 3.35 & $*$ & 2.44 & $*$ \\
\hline
\end{tabular}

Note: ns $=$ effect of treatment or interaction were not significant; * and ** were significant at $P \leq 0.05$ and $P \leq 0.01$, respectively.

Most of reproductive traits did not significantly affected by different water regimes and NPK application rates up to $2 \mathrm{~g} /$ plant. These reproductive traits in black glutinous rice seemed to be predominantly regulated by genetic factor.

Continuous 3-cm depth flooding (W1) exhibited consistently higher total and productive tillers, leaf and stem dry weight, number of leaves per plant, percentage of filled grain, and grain yield in black glutinous rice plants than those treated with alternate water saturated and gradual drying conditions (W2). Plants steadily exposed to shallow water table at depth of $3 \mathrm{~cm}$ below substrate surface (W3) performed better than the alternate wetting-drying treated plants (W2) on total and productive tillers, percentage of filled grain, and grain yield (Table 2).

NPK application was effective in increasing grain yield and some vegetative traits in the black glutinous rice. The highest grain yield, total and productive tillers were found at $320 \mathrm{~kg} / \mathrm{ha}$ NPK application rate (P4) (Table 3). 
Table 2. Alternate aerobic-anaerobic condition significantly decreased some vegetative traits, percentage of filled grain, and grain yield compared to continuous flooding in ratooned black glutinous rice.

\begin{tabular}{|c|c|c|c|c|c|c|c|}
\hline \multirow{2}{*}{$\begin{array}{l}\text { Water } \\
\text { regime }\end{array}$} & \multirow{2}{*}{$\begin{array}{c}\text { Filled } \\
\text { grain } \\
(\%)\end{array}$} & \multirow{2}{*}{$\begin{array}{c}\text { Stem } \\
\text { Dry } \\
\text { weight } \\
\text { (g) }\end{array}$} & \multicolumn{2}{|c|}{ Leaf } & \multicolumn{2}{|c|}{ Tiller } & \multirow{2}{*}{$\begin{array}{c}\text { Grain } \\
\text { Yield } \\
\text { (ton/ha) }\end{array}$} \\
\hline & & & $\begin{array}{c}\text { weight } \\
\text { (g) }\end{array}$ & Number & Total & Productive & \\
\hline W1 & $81.27 \mathrm{~b}$ & $6.90 \mathrm{~b}$ & $4.72 \mathrm{~b}$ & $32.71 \mathrm{~b}$ & $15.04 \mathrm{~b}$ & $10.54 \mathrm{~b}$ & $1.53 \mathrm{~b}$ \\
\hline W2 & $74.11 \mathrm{a}$ & $3.79 \mathrm{a}$ & $2.38 \mathrm{a}$ & $26.71 \mathrm{a}$ & $9.26 \mathrm{a}$ & $7.20 \mathrm{a}$ & $0.93 \mathrm{a}$ \\
\hline W3 & $80.44 b$ & $5.02 \mathrm{a}$ & $3.19 \mathrm{a}$ & $22.25 \mathrm{a}$ & $14.82 \mathrm{~b}$ & $11.19 b$ & $1.47 \mathrm{~b}$ \\
\hline
\end{tabular}

Note: $\mathrm{W} 1=$ Continuous flooding at depth of $3 \mathrm{~cm}$; W2 = Alternate treatment with water saturated (anaerobic) condition and gradual drying (partially aerobic) condition; and W3 = steadily exposed to shallow water table ( $3 \mathrm{~cm}$ below substrate surface). Means followed by similar letters within each column are not significantly different based on $\mathrm{LSD}_{.05}$.

Table 3. Higher rates of NPK application increased number of leaves, total and productive tillers, and grain yield in ratooned black glutinous rice.

\begin{tabular}{|c|c|c|c|c|c|}
\hline \multirow{2}{*}{$\begin{array}{l}\text { Rate of NPK } \\
\text { application }\end{array}$} & \multirow{2}{*}{$\begin{array}{c}\text { Number of } \\
\text { leaves }\end{array}$} & \multicolumn{2}{|c|}{ Number of tillers } & \multirow{2}{*}{\multicolumn{2}{|c|}{ Grain Yield (ton/ha) }} \\
\hline & & Total & Productive & & \\
\hline $\mathrm{P} 1$ & $22.28 \mathrm{a}$ & $11.22 \mathrm{ab}$ & $10.17 \quad b$ & 1.15 & $\mathrm{ab}$ \\
\hline $\mathrm{P} 2$ & $24.32 \mathrm{ab}$ & $10.65 \mathrm{a}$ & 6.88 & 0.99 & $\mathrm{a}$ \\
\hline P3 & 33.41 & $13.77 \mathrm{ab}$ & 10.02 & 1.42 & $\mathrm{bc}$ \\
\hline $\mathrm{P} 4$ & 28.89 & $16.51 \mathrm{~b}$ & 11.51 & 1.68 & $\mathrm{c}$ \\
\hline
\end{tabular}

Note: P1, P2, P3, and P4 are NPK fertilizer application at rates equivalent to 80, 160, 240, and $320 \mathrm{~kg} / \mathrm{ha}$, respectively. Means followed by similar letters within each column are not significantly different based on $\mathrm{LSD}_{.05}$.

Gain yield of ratooned rice was slightly more than 1.5 ton/ha or less than half of main rice productivity, even at the highest NPK application rate (P4). However, ratooned rice was harvested within very short time, i.e. only within two months after harvest of the main rice crop. Under condition when second rice growing season is impossible to be conducted, half yield within half growing season is a great option for increasing rice production at riparian wetlands. Combination of continuous flooding (W1) or steady shallow water table (W3) with NPK application rate at $2 \mathrm{~g} /$ plant (P4) produced significantly higher grain yield compared to all other possible combinations (Table 4). 
Table 4. Interactions between water regime and rate of NPK application were observed in some vegetative traits, total grain weight per peduncle, and grain yield in ratooned black glutinous rice.

\begin{tabular}{|c|c|c|c|c|c|c|c|}
\hline \multirow[b]{2}{*}{$\begin{array}{l}\text { Water } \\
\text { regime }\end{array}$} & \multirow{2}{*}{$\begin{array}{l}\text { Grain } \\
\text { weight } \\
\text { /peduncle } \\
\text { (g) }\end{array}$} & \multirow{2}{*}{$\begin{array}{l}\text { Stem } \\
\text { Dry } \\
\text { weight } \\
\text { (g) }\end{array}$} & \multirow{2}{*}{$\begin{array}{l}\text { Leaf } \\
\text { Dry } \\
\text { weight } \\
\text { (g) }\end{array}$} & \multicolumn{3}{|c|}{ Tiller } & \multirow[b]{2}{*}{$\begin{array}{l}\text { Grain } \\
\text { Yield } \\
\text { (ton/ha) }\end{array}$} \\
\hline & & & & Number & Total & Productive & \\
\hline W1P1 & $0.95 \mathrm{ab}$ & $3.31 \mathrm{a}$ & $2.14 \mathrm{a}$ & $16.67 \mathrm{a}$ & $8.50 \mathrm{a}$ & $8.00 \mathrm{a}$ & $0.87 \mathrm{a}$ \\
\hline W1P2 & $1.49 \mathrm{~d}$ & $8.00 \mathrm{~d}$ & $4.14 \mathrm{ab}$ & $24.75 \mathrm{ab}$ & $12.75 \mathrm{abc}$ & $7.50 \mathrm{a}$ & $1.41 \mathrm{abc}$ \\
\hline W1P3 & $1.28 \mathrm{~cd}$ & $8.11 \mathrm{~d}$ & $8.20 \mathrm{c}$ & $59.75 \mathrm{c}$ & $22.25 \mathrm{e}$ & $13.00 \mathrm{~b}$ & $1.96 \mathrm{~cd}$ \\
\hline W1P4 & $1.04 \mathrm{abc}$ & $8.17 \mathrm{~d}$ & $4.40 \mathrm{ab}$ & $29.67 \mathrm{~b}$ & $16.17 \mathrm{~cd}$ & $13.67 \mathrm{~b}$ & $2.27 \mathrm{~d}$ \\
\hline W2P1 & $1.23 \mathrm{bcd}$ & $2.55 \mathrm{a}$ & $2.26 \mathrm{ab}$ & $24.17 \mathrm{ab}$ & $9.25 \mathrm{ab}$ & $7.00 \mathrm{a}$ & $0.96 \mathrm{a}$ \\
\hline W2P2 & $1.06 \mathrm{abc}$ & $4.16 \mathrm{ab}$ & $2.08 \mathrm{a}$ & $26.00 \mathrm{ab}$ & $8.00 \mathrm{a}$ & $5.33 \mathrm{a}$ & $0.80 \mathrm{a}$ \\
\hline W2P3 & $1.09 \mathrm{abc}$ & $3.72 \mathrm{a}$ & $2.47 \mathrm{ab}$ & $23.67 \mathrm{ab}$ & $8.67 \mathrm{a}$ & $8.67 \mathrm{a}$ & $1.07 \mathrm{ab}$ \\
\hline W2P4 & $1.00 \mathrm{abc}$ & $4.72 \mathrm{abc}$ & $3.45 \mathrm{ab}$ & $33.00 \mathrm{~b}$ & $14.20 \mathrm{bcd}$ & $7.80 \mathrm{a}$ & $0.88 \mathrm{a}$ \\
\hline W3P1 & $0.90 \mathrm{a}$ & $6.69 \mathrm{~cd}$ & $4.55 \mathrm{~b}$ & $26.00 \mathrm{ab}$ & $19.00 \mathrm{de}$ & $15.50 \mathrm{~b}$ & $1.64 \mathrm{bcd}$ \\
\hline W3P2 & $0.92 \mathrm{a}$ & $3.66 \mathrm{a}$ & $2.49 \mathrm{ab}$ & $22.20 \mathrm{ab}$ & $11.20 \mathrm{abc}$ & $7.80 \mathrm{a}$ & $0.76 \mathrm{a}$ \\
\hline W3P3 & $1.42 \mathrm{~d}$ & $3.28 \mathrm{a}$ & $2.34 \mathrm{ab}$ & $16.80 \mathrm{a}$ & $10.40 \mathrm{ab}$ & $8.40 \mathrm{a}$ & $1.23 \mathrm{ab}$ \\
\hline W3P4 & $1.26 \mathrm{~cd}$ & $6.47 \mathrm{bcd}$ & $3.38 \mathrm{ab}$ & $24.00 \mathrm{ab}$ & $18.67 \mathrm{de}$ & $15.67 \mathrm{~b}$ & $2.26 \mathrm{~d}$ \\
\hline
\end{tabular}

Note: W1 to W3 are as mentioned at Table 2. P1 to P4 are as mentioned at Table 3. Means followed by similar letters within each column are not significantly different based on LSD.05.

Continuous flooding was effective in controlling weed outburst during cultivation of ratooned black glutinous rice even without any herbicide application or other weeding practices. Very limited aquatic weed was found and only yellow velvetleaf (Limnocharis flava) was consistently observed in continuous flooding treatment. In contrast, steady shallow water table treatment was highly invaded with many different weeds, including Imperata cylindrica, Phyllanthus urinaria, Impatiens balsamina, Digitaria adscendens, Hedyotis corymbosa, Eleusine indica, Physalis peruviana, Borreria laevis, Pennisetum purpureum, Marsilea clover, Chromolaena odorata, Synedrella nodiflora, Cyperus kyllingia, Hedyotis corymbosa, Cleome rutidosperma, and Limnocharis flava. Total dry biomass of weeds was significantly higher in unflooded shallow water table treatment (Table 5). 
Table 5. Weed biomass as affected by water regime and rate of NPK application during cultivation of ratooned black glutinous rice

\begin{tabular}{|c|c|c|c|c|c|}
\hline $\begin{array}{l}\text { Water } \\
\text { regime }\end{array}$ & $\begin{array}{l}\text { Weed dry } \\
\text { weight (g) }\end{array}$ & NPK rate & $\begin{array}{l}\text { Weed dry } \\
\text { weight (g) }\end{array}$ & Interaction & $\begin{array}{l}\text { Weed dry } \\
\text { weight (g) }\end{array}$ \\
\hline W1 & $2.57 \mathrm{a}$ & P1 & $4.95 \mathrm{a}$ & W1P1 & $4.03 \mathrm{~cd}$ \\
\hline W2 & $5.32 \mathrm{~b}$ & $\mathrm{P} 2$ & $4.93 \mathrm{a}$ & W1P2 & $0.95 \mathrm{a}$ \\
\hline \multirow[t]{10}{*}{ W3 } & $8.17 \mathrm{c}$ & P3 & $5.59 \mathrm{a}$ & W1P3 & $4.39 \mathrm{~cd}$ \\
\hline & & P4 & $5.96 \mathrm{a}$ & W1P4 & $1.00 \mathrm{ab}$ \\
\hline & & & & W2P1 & $2.39 \mathrm{abc}$ \\
\hline & & & & $\mathrm{W} 2 \mathrm{P} 2$ & $6.11 \mathrm{de}$ \\
\hline & & & & W2P3 & $3.73 \mathrm{bcd}$ \\
\hline & & & & W2P4 & $9.05 \mathrm{f}$ \\
\hline & & & & W3P1 & 8.42 ef \\
\hline & & & & W3P2 & 7.80 ef \\
\hline & & & & W3P3 & 8.65 ef \\
\hline & & & & W3P4 & 7.83 ef \\
\hline
\end{tabular}

Note: W1 to W3 are as mentioned at Table 2. P1 to P4 are as mentioned at Table 3. Means followed by similar letters within each column are not significantly different based on LSD .05 .

The most reliable in-season predictor for grain yield in black glutinous rice was number of productive tillers per hill $(\mathrm{r}=0.8499)$. Total number of tillers and leaf dry weight were moderately reliable predictors, with $r=0.6334$ and 0.6275 , respectively (Figure 1). 

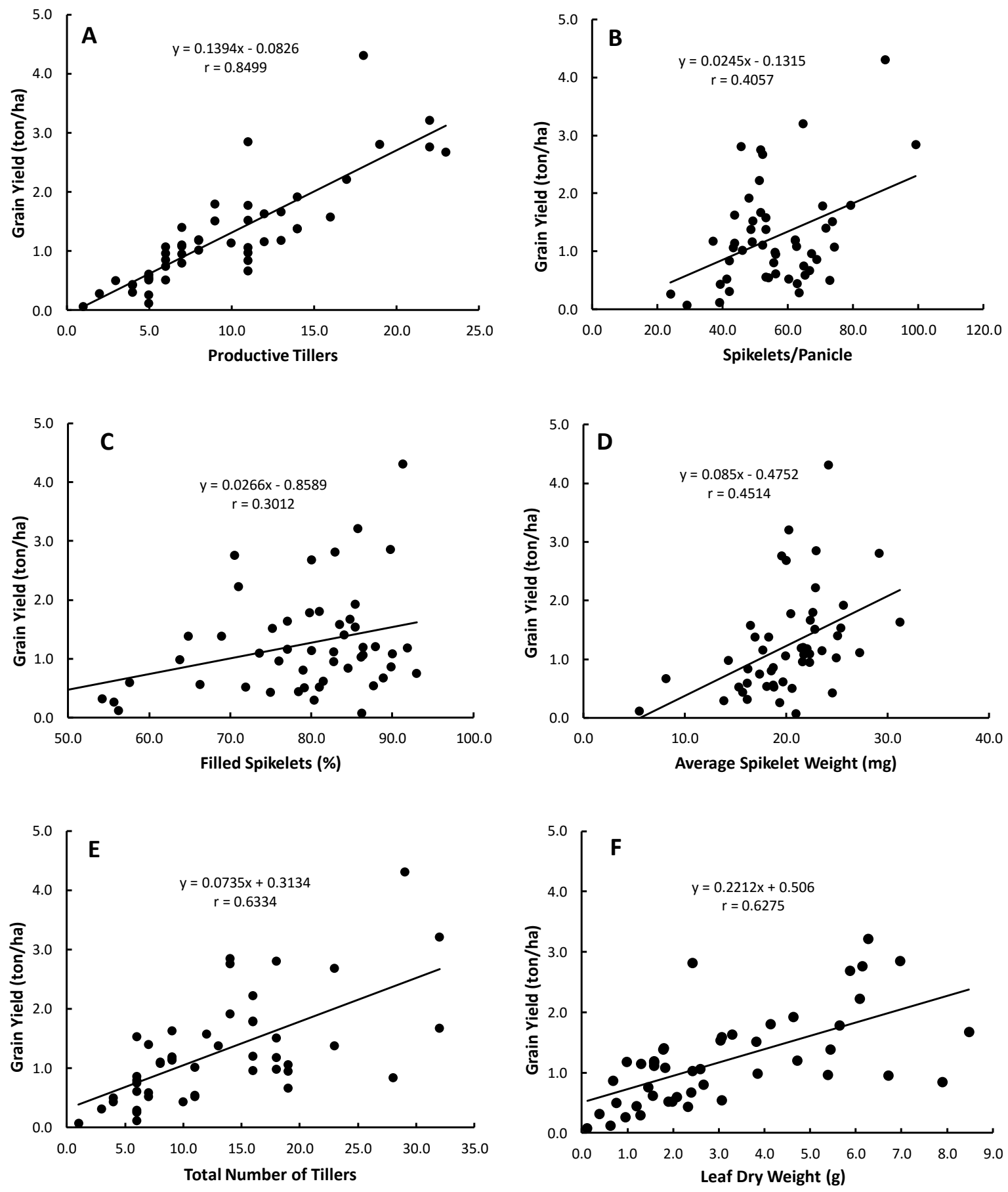

Figure 1. Correlations of some vegetative and reproductive traits with grain yield in ratooned black glutinous rice

\section{DISCUSSION}

\section{Growth and yield under different water regimes}

Limited studies had been conducted for comparing continuous flooding, alternate wetting-drying, and shallow water table to find workable solution under unpredictable climate in riparian wetlands. Studies on continuous flooding were mostly focused on effect of oxygen deficiency in rhizosphere (Yamauchi 
et al., 2018). Objective of alternate wetting-drying studies in rice were mostly for increasing water use efficiency (Chu et al., 2018). Studies on shallow water table were mostly conducted in association with efforts for expanding agriculture activity to wetland ecosystem (Lakitan et al., 2018c; Susilawati and Lakitan, 2019).

Continuous flooding after harvest of main rice crop due to extended rainy season was not expected to restrain growth and yield in ratooned rice. Result of this research confirmed this prediction (Table 2). Rice has been well known as highly adaptable crop to waterlogging or flooding condition due to its ability to supply oxygen internally to roots via aerenchyma (Takahashi et al., 2018).

Alternate wetting and drying condition can occur naturally or intentionally managed using irrigation system. Alternate wetting-drying treatment has been reported to increase nitrogen availability and uptake by plant roots (de Borja-Reis et al., 2018), also increased efficiency of nitrogen recovery (Sun et al., 2019). However, Huda et al. (2016) found alternate wetting and drying condition had no significant effect on grain yield or on $\mathrm{N}$ use efficiency in rice. Furthermore, despite increasing water use efficiency by $23 \%$, Carrijo et al. (2017) found that alternate wetting-drying condition reduced grain yield in rice. This inconsistent result implies that other significant factor(s) has been neglected, more likely degree of control on weeds during each study. Favorable substrate or soil condition due to alternate wetting-drying condition provides benefits not only to rice crop but also to existing weeds. Therefore, it creates competition between rice and weeds. In this study, weeds were not intentionally controlled, as practiced by smallholder rice farmers at riparian wetlands due to socio-economical constraint.

Steady shallow water table may significantly reduce yield; however, it depends on the depth of water table and species of cultivated crops. For instance, yield of common bean significantly reduced if water table was at depth of less than $10 \mathrm{~cm}$ below soil surface. However, the water table at depth of $15 \mathrm{~cm}$ or deeper did not significantly affect common bean yield even if this shallow water table was exposed up to 24 days (Lakitan et al., 2018c; Susilawati and Lakitan, 2019).

Constant shallow water table treatment at $3-\mathrm{cm}$ below substrate surface produced comparable productive tillers, percentage of filled grain, and grain yield to those of continuous flooding treatment. This result suggested that black glutinous rice could withstand continuous flooding and steady shallow water table, but it was not able to quickly adapt to frequent (every 3-day cycle) alternate wetting and drying. 


\section{Additional inorganic NPK to soil-manure mix}

Availability of manure or other organic fertilizer was very limited at riparian wetlands; therefore, local farmers commonly applied urea or NPK fertilizer for increasing productivity of their crops. In this study, growth and yield of ratooned rice was significantly increased by NPK application up to $2 \mathrm{~g} / \mathrm{plant}$ (Table 3), equivalent to $320 \mathrm{~kg} / \mathrm{ha}$. Similarly, Liu et al. (2014) reported that rice plants grown on flooded paddy fields responded to NPK application by increasing grain yield 1.65 to 1.80 -folds. However, increase in grain yield by applying inorganic NPK fertilizer does not always translate into financial benefit to smallholder rice farmers in developing countries. Haefele et al. (2010) found that commercial organic fertilizer increased yields but resulted in negative economic returns in almost all cases covered by their study because of its unfavorable nutrient/price ratio.

Some efforts have been practiced for reducing rates of inorganic fertilizer application, including use of NPK briquette and polymer-coated urea. Islam et al. (2011) reported that the highest grain yield of 7.47 ton/ha was achieved in their study by application of NPK briquette at rates of $2.4 \mathrm{~g} \times 2$ at tidal flooded ecosystem in Bangladesh. Meanwhile, Sun et al. (2019) found that polymercoated urea application significantly increased $\mathrm{N}$ uptake, $\mathrm{N}$ recovery efficiency, and grain yield in both flooded and non-flooded cultivation systems.

Application rates of inorganic fertilizer can also be reduced by combining inorganic and organic fertilizers. Use of 4 ton/ha poultry manure reduced rate of NPK application to half of recommended rate (Hasanuzzaman et al., 2010). Meanwhile, returning rice straw to paddy field after previous harvest decreased the required NPK application as much as 15 percent (Wu et al., 2018). However, in this study, the highest grain yield was achieved at highest application rate of 2 $\mathrm{g} /$ plant despite manure has also been added into the substrate used. Therefore, NPK application rate is recommended for achieving higher grain yield in ratooned black glutinous rice cultivated at riparian wetlands.

\section{Traits for predicting in-season grain yield in ratooned black glutinous rice}

Hefena et al. (2016) evoked that number of panicles, 1,000-grain weight, number of filled grains per panicle, and panicle weight in rice plants could be used as predictor for grain yield among rice genotypes. Ata-Ul-Karim et al. (2016) and Naito et al. (2017) had tested relationship between rice grain yield and leaf nitrogen content. Ata-Ul-Karim et al. (2016) found that nitrogen nutrition index, accumulated nitrogen deficit, and nitrogen requirement at different growth stages were significantly correlated with grain yield in rice plants, with all $\mathrm{R}^{2}$ higher than 0.74 for Japonica dan Indica rice. The strongest correlations were found for measurements during panicle initiation and booting stages.

Hefena et al. (2016) compared among several vegetation indices, including simple trait ratio, normalized difference vegetation index, transformed vegetation 
index, corrected transformed vegetation index, soil-adjusted vegetation index, modified soil-adjusted vegetation index, and multiple yield traits. They found that among all indices studied, simple trait ratio exhibited the best performance for estimation of grain weight in rice plant $\left(\mathrm{R}^{2}=0.80\right)$.

In this study, predictors for in-season grain yield were intentionally selected amongst primary traits of rice plant, such that they can be easily used by local farmers. It was found that the most reliable predictor $(r=0.8499)$ for grain yield in black glutinous rice was number of productive tillers per hill (Figure 1).

\section{Water regimes and weed outburst}

Grass weeds were thicker at dry direct-seeded rice that those at puddled and non-puddled transplanted rice (Chauhan et al., 2015). Correspondingly, the yield losses due to weeds varied from $50 \%$ to $60 \%$ at puddled transplanted rice but more severe losses of $70 \%$ to $80 \%$ were observed at dry direct-seeded rice (Dass et al., 2017).

In this study, aerobic upper substrate layer in steady shallow water table treatment was heavily invaded by at least 16 species of weeds. Total dry weight of weeds was significantly higher at this non-flooded condition (Table 5). However, despite highly invested by weeds, grain yield in ratooned black glutinous rice did not significantly decreased in shallow water table treatment compared to continuous flooding treatment (Table 2). The insignificant yield reduction was associated (at least partially) with short period of ratooned rice cultivation. At time of the weeds densely invaded the growing space, the ratooned rice had reached seed filling stage.

\section{ACKNOWLEDGEMENTS}

We would like to thank the Editor-in-Chief of this journal and anonymous reviewers for their constructive comments, suggestions, and corrections to earlier versions of this manuscript. This work was supported by Program Penelitian Unggulan Profesi Universitas Sriwijaya (Grant No.0014/UN9/SK.LP2M.PT/ 2019).

\section{REFERENCES}

Adigbo, S.O., Odedina, J.N., Afolabi, C.G., Osipitan, A.A., Agbonlahor, M., Fabunmi, T.O., Adejuyigbe, C.O., Atanda, F.G., and Nweke-Okoh, M.L. 2017. Response of lowland rice-ratooned rice-fluted pumpkin sequence to fertilizer in rainfed inland valley in derived savannah of Nigeria. Acta Agriculturae Slovenica. 109(1): 43-52. https://doi.org/10.14720/aas.2017. 109.1.04 
Ata-Ul-Karim, S.T., Liu, X., Lu, Z., Yuan, Z., Zhu, Y., and Cao, W. 2016. In-season estimation of rice grain yield using critical nitrogen dilution curve. Field Crops Research. 195: 1-8. https://doi.org/10.1016/j.fcr. 2016.04.027

Carrijo, D.R., Lundy, M.E., and Linquist, B.A. 2017. Rice yields and water use under alternate wetting and drying irrigation: a meta-analysis. Field Crops Research. 203: 173-180. https://doi.org/10.1016/j.fcr.2016.12.002

Chauhan, B.S., Awan, T.H., Abugho, S.B., and Evengelista, G. 2015. Effect of crop establishment methods and weed control treatments on weed management, and rice yield. Field Crops Research. 172: 72-84. https://doi.org/10.1016/j.fcr.2014.12.011

Chen, H., Yang, D., Liang, Y., Zhang, Z., Liang, K., and Lin, W. 2010. Effect of nitrogen application strategy in the first cropping rice on dry matter accumulation, grain yield and nitrogen utilization efficiency of the first cropping rice and its ratoon rice crop. Chinese Journal of EcoAgriculture. 18(1): 50-56. https://doi.org/10.3724/SP.J.1011.2010.00050

Chen, Q., He, A., Wang, W., Peng, S., Huang, J., Cui, K., and Nie, L. 2018. Comparisons of regeneration rate and yields performance between inbred and hybrid rice cultivars in a direct seeding rice-ratoon rice system in central China. Field Crops Research. 223: 164-170. https://doi.org/10. 1016/j.fcr.2018.04.010

Chipanshi, A., Zhang, Y., Kouadio, L., Newlands, N., Davidson, A., Hill, H., Warren, R., Qian, B., Daneshfar, B., Bedard, F., et al. 2015. Evaluation of the Integrated Canadian Crop Yield Forecaster (ICCYF) model for inseason prediction of crop yield across the Canadian agricultural landscape. Agricultural and Forest Meteorology. 206: 137-150. https://doi.org/10. 1016/j.agrformet.2015.03.007

Chu, G., Chen, T., Chen, S., Xu, C., Wang, D., and Zhang, X. 2018. The effect of alternate wetting and severe drying irrigation on grain yield and water use efficiency of Indica-japonica hybrid rice (Oryza sativa L.). Food and Energy Security. 7(2): e00133. https://doi.org/10.1002/fes3.133

Dass, A., Shekhawat, K., Choudhary, A.K., Sepat, S., Rathore, S.S., Mahajan, G., and Chauhan, B.S. 2017. Weed management in rice using crop competition-a review. Crop Protection. 95:45-52. https://doi.org/10. 1016/j.cropro.2016.08.005

de Borja-Reis, A.F., Vasconcelos, A.L.S., de Almeida, R.E.M., Lago, B.C., Dias, C.T.S., and Favarin, J.L. 2018. Relationship of nitrogen and crop performance in aerobic rice and continuous flooding irrigation in weathered tropical lowland. European Journal of Agronomy. 95: 14-23. https://doi.org/10.1016/j.eja.2018.01.016 
Hasanuzzaman, M., Ahamed, K.U., Rahmatullah, M., Akhter, N., Nahar, K., and Rahman, M.L. 2010. Plant growth characters and productivity of wetland rice (Oryza sativa L.) as affected by application of different manures. Emirates Journal of Food and Agriculture. 22(1): 46-58.

Haefele, S.M., Sipaseuth, N., Phengsouvanna, V., Dounphady, K., and Vongsouthi, S. 2010. Agro-economic evaluation of fertilizer recommendations for rainfed lowland rice. Field Crops Research. 119(2-3): 215-224. https://doi.org/10.1016/j.fcr.2010.07.002

Hafeez, S., Jin, T., and Zhou, Y. 2017. Factors affecting yield and yield components of main and ratoon rice: a review. Agricultural Science and Technology. 18(7): 1228-1231.

Hefena, A.G., Sultan, M.S., Abdel-Moneam, M.A., Hammoud, S.A., Barutçular, C., and El-Sabagh, A. 2016. Genetic variability, heritability and genetic advance for yield and associated traits in $\mathrm{F} 2$ rice population. Journal of Agriculture Biotechnology. 1(02), online article.

Huda, A., Gaihre, Y.K., Islam, M.R., Singh, U., Islam, M.R., Sanabria, J., Satter, M.A., Afroz, H., Halder, A., and Jahiruddin, M. 2016. Floodwater ammonium, nitrogen use efficiency and rice yields with fertilizer deep placement and alternate wetting and drying under triple rice cropping systems. Nutrient Cycling in Agroecosystems. 104(1): 53-66. https://doi. org/10.1007/s10705-015-9758-6

Huossainzade, A., Azarpour, E., Doustan, H.Z., Moraditochaee, M., and Bozorgi, H.R. 2011. Management of cutting height and nitrogen fertilizer rates on grain yield and several attributes of ratoon rice (Oryza sativa L.) in Iran. World Applied Sciences Journal. 15(8): 1089-1094.

Islam, M.S., Rahman, F., and Hossain, A.T.M.S. 2011. Effects of NPK briquette on rice (Oryza sativa) in tidal flooded ecosystem. The Agriculturists. 9(1-2): 37-43. https://doi.org/10.3329/agric.v9i1-2.9477

Lakitan, B., Hadi, B., Herlinda, S., Siaga, E., Widuri, L.I., Kartika, K., Lindiana, L., Yunindyawati, Y., and Meihana, M. 2018a. Recognizing farmers' practices and constraints for intensifying rice production at Riparian Wetlands in Indonesia. NJAS-Wageningen Journal of Life Sciences. 85: 10-20.

Lakitan, B., Iwanaga, H., Kartika, K., Kriswantoro, H., and Sakagami, J.I. 2018 b. Adaptability to varying water levels and responsiveness to NPK fertilizer in yellow velvetleaf plant (Limnocharis flava). Australian Journal of Crop Science. 12(11): 1757-1764. https://doi.org/10.21475/ajcs.18.12.11.p1451

Lakitan, B., Kadir, S., and Wijaya, A. 2018c. Tolerance of common bean (Phaseolus vulgaris L.) to different durations of simulated shallow water table condition. Australian Journal of Crop Science. 12(4): 661-668. https://doi.org/10.21475/ajcs.18.12.04.pne1047 
Lakitan, B., Lindiana, L., Widuri, L.I., Kartika, K., Siaga, E., Meihana, M., and Wijaya, A. 2019a. Inclusive and ecologically-sound food crop cultivation at tropical non-tidal Wetlands in Indonesia. AGRIVITA Journal of Agricultural Science. 41(1): 23-31. https://doi.org/10.17503/agrivita. v40i0.1717

Lakitan, B., Juliani, F., and Sodikin, E. 2019b. Ability of Limnocharis flava to escape from episodic submersion by rapid elongation of its leaf petiole. Bulgarian Journal of Agricultural Science. 25(2): 314-319.

Liu, S., Huang, D., Chen, A., Wei, W., Brookes, P.C., Li, Y., and Wu J. 2014. Differential responses of crop yields and soil organic carbon stock to fertilization and rice straw incorporation in three cropping systems in the subtropics. Agriculture, Ecosystems and Environment. 184: 51-58. https://doi.org/10.1016/j.agee.2013.11.019

Mareza, E., Djafar, Z.R., Suwignyo, R.A., and Wijaya, A. 2016. Rice ratoon yield response to main crops cutting height in tidal swamp using direct seeding system. AGRIVITA, Journal of Agricultural Science. 38(2): 126-132. https://doi.org/10.17503/agrivita.v38i2.502

Meihana, M., Lakitan, B., Susilawati, M.U., Widuri, L.I., Kartika, K., Siaga, E., and Kriswantoro, H. 2017. Steady shallow water table did not decrease leaf expansion rate, specific leaf weight, and specific leaf water content in tomato plants. Australian Journal of Crop Science. 11(12): 1635-1641. https://doi.org/10.21475/ajcs.17.11.12.pne808

Naito, H., Ogawa, S., Valencia, M.O., Mohri, H., Urano, Y., Hosoi, F., Shimizu, Y., Chaves, A.L., Ishitani, M., Selvaraj, M.G., et al. 2017. Estimating rice yield related traits and quantitative trait loci analysis under different nitrogen treatments using a simple tower-based field phenotyping system with modified single-lens reflex cameras. ISPRS Journal of Photogrammetry and Remote Sensing. 125: 50-62. https://doi.org/10. 1016/j.isprsjprs.2017.01.010

Petroudi, E.R., Noormohammadi, G., Mirhadi, M.J., Madani, H., and Mobasser, H.R. 2011. Effects of nitrogen fertilization and rice harvest height on agronomic yield indices of ratoon rice-berseem clover intercropping system. Australian Journal of Crop Science. 5(5): 566-574.

Sen, L.T.H., and Bond, J. 2017. Agricultural adaptation to flood in lowland rice production areas of Central Vietnam: understanding the regenerated rice ratoon system. Climate and Development. 9(3): 274-285. https://doi.org/ 10.1080/17565529.2016.1149440

Sun, Y., Mi, W., Su, L., Shan, Y., and Wu, L. 2019. Controlled-release fertilizer enhances rice grain yield and $\mathrm{N}$ recovery efficiency in continuous nonflooding plastic film mulching cultivation system. Field Crops Research. 231: 122-129. https://doi.org/10.1016/j.fcr.2018.11.013 
Susilawati, and Lakitan, B. 2019. Cultivation of common bean (Phaseolus vulgaris L.) subjected to shallow water table at riparian wetland in South Sumatra, Indonesia. Australian Journal of Crop Science. 13(1): 98-104. https://doi.org/10.21475/ajcs.19.13.01.p1298

Takahashi, H., Xiaohua, Q., Shimamura, S., Yanagawa, A., Hiraga, S., and Nakazono, M. 2018. Sucrose supply from leaves is required for aerenchymatous phellem formation in hypocotyl of soybean under waterlogged conditions. Annals of Botany. 121(4): 723-732. https:// doi.org/10.1093/aob/mcx205

Thiranusornkij, L., Thamnarathip, P., Chandrachai, A., Kuakpetoon, D., and Adisakwattana, S. 2019. Comparative studies on physicochemical properties, starch hydrolysis, predicted glycemic index of Hom Mali rice and riceberry rice flour and their applications in bread. Food Chemistry. 283: 224-231. https://doi.org/10.1016/j.foodchem.2019.01.048

Widuri, L.I., Lakitan, B., Hasmeda, M., Sodikin, E., Wijaya, A., Meihana, M., Kartika, K., and Siaga, E. 2017. Relative leaf expansion rate and other leaf-related indicators for detection of drought stress in chili pepper (Capsicum annuum L.). Australian Journal of Crop Science. 11(12): 16171625. https://doi.org/10.21475/ajcs.17.11.12.pne800

Widuri, L.I., Lakitan, B., Sodikin, E., Hasmeda, M., Meihana, M., Kartika, K., and Siaga, E. 2018. Shoot and root growth in common bean (Phaseolus vulgaris L.) exposed to gradual drought stress. AGRIVITA Journal of Agricultural Science. 40(3): 442-452. https://doi.org/10.17503/agrivita. v40i0.1716

Wu, Y., Hao, X., Tian, X., Chen, Y., Zhang, C., Cheng, H., Li, H., Qin, Y., and Zhao, S. 2018. Effects of reduction of NPK fertilizer application rates plus rice straw return on soil nutrient, enzyme activities and wheat yield in rice-wheat rotation system. Southwest China Journal of Agricultural Sciences. 31(5): 998-1005

Yamauchi, T., Colmer, T.D., Pedersen, O., and Nakazono, M. 2018. Regulation of root traits for internal aeration and tolerance to soil waterloggingflooding stress. Plant Physiology. 176(2): 1118-1130. https://doi.org/10. 1104/pp.17.01157

Yuan, S., Cassman, K.G., Huang, J., Peng, S., and Grassini, P. 2019. Can ratoon cropping improve resource use efficiencies and profitability of rice in central China? Field Crops Research. 234: 66-72. https://doi.org/10.1016/ j.fcr.2019.02.004

Ziska, L.H., Fleisher, D.H., and Linscombe, S. 2018. Ratooning as an adaptive management tool for climatic change in rice systems along a north-south transect in the southern Mississippi valley. Agricultural and Forest Meterology. 263: 409-416. https://doi.org/10.1016.j.agrformet.2018.09. 010 